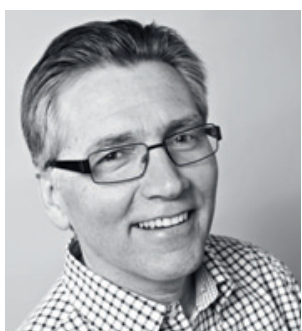

Petter Gjersvik (f. 1952) er medisinsk redaktør

i Tidsskriftet. Han er hudlege, dr.med. og

førsteamanuensis og undervisningsleder

for dermatologi og venerologi ved Oslo

universitetssykehus, Rikshospitalet.

Foto Einar Nilsen

Nye eksamensformer i medisinstudiet har medført bedre og mer valid testing av kunnskaper

og kliniske ferdigheter

\title{
En bedre eksamen
}

Eksamen er en nødvendig del av legeutdanningen. Eksamen skal sikre at studentene har tilstrekkelige kunnskaper og ferdigheter til å være leger. Samtidig styrer eksamen studentenes studieatferd: De prioriterer kunnskap og ferdigheter som de vet kan inngå i eksamen. For lærerne gir eksamensprestasjonene ideer til forbedringer av undervisningen.

To eksamensformer har lenge stått sentralt innen medisinsk utdanning: skriftlig eksamen, der studentene skal redegjøre for ett eller flere emner, og klinisk eksamen, med pasientundersøkelse og muntlig eksaminering. Svakheten ved slike eksamensformer er mange - bl.a. at de bare dekker en liten del av fagområdet og klinisk praksis (lav validitet), at karakterfastsettelsen er preget av tilfeldigheter og usikkerhet (lav reliabilitet), og at gjennomføringen krever mye tid og ressurser (1).

De siste tiårene har bruk av flervalgsoppgaver ved skriftlig eksamen (multiple choice questions) slått igjennom som eksamensform ved mange medisinske studiesteder og av sertifiseringsmyndigheter (2, 3), også i Norge (4). Flervalgsoppgaver innebærer at kandidatene blir bedt om å krysse av for ett (eller flere) riktige svaralternativer på et gitt spørsmål. Slike oppgaver innebærer bedre validitet av eksamen som helhet, bedre reliabilitet ved karakterfastsettelsen og at mange kandidater kan testes med rimelig bruk av tid og ressurser. Svakheten er at oppgavene kan være vanskelige å lage og at de motiverer mer til overflatelæring og kunnskapsreproduksjon enn til refleksjon, dybdeforståelse og ferdighetstrening (2). Bruk av sant/usant-utsagn (true/false) er en variant av flervalgsoppgaver med bare to svaralternativer. Kortsvarsoppgaver (short answer questions) brukes også. Disse er vanskeligere å skåre $\mathrm{og}$ krever prosedyrer for å sikre mest mulig reliable skåringer (2).

Like viktig som å ha kunnskaper er det at studentene kan anvende kunnskapen i kliniske situasjoner, gjennomføre praktiske prosedyrer og kommunisere med pasientene. Slike ferdigheter kan ikke testes med skriftlig eksamen. I slutten av 1970-årene introduserte to britiske eksperter i medisinsk pedagogikk en eksamensform de kalte objektiv, strukturert klinisk eksamen (Objective Structured Clinical Exams; OSCE) (5). Denne eksamensformen innebærer at kandidatene blir presentert for kliniske og praktiske oppgaver som skal løses innen et begrenset antall minutter. En faglærer skårer kandidatens prestasjon basert på en forhåndsoppsatt standardisert skåringsmal. På denne måten blir skåringsvariasjonen mellom ulike skårere mindre og behovet for skjønn begrenset. Oppgavene blir presentert etter hverandre på «stasjoner» av 5-15 minutters varighet, som alle kandidatene skal gjennomgå etter tur. Studentene får altså identiske oppgaver, og kravet til bestått eksamen vil være tydeligere og bedre definert. Det finnes ikke noen «sannhet» for hva som er «riktig» krav til bestått - det viktigste er at grunnlaget for vurderingen er så valid som mulig (2). Vurderingen vil i praksis være basert på et faglig og saklig skjønn $(2,6)$.

Stasjonseksamen i ulike varianter benyttes i dag ved et økende antall medisinske studiesteder verden over. OSCE-formen har sine begrensninger og kan modifiseres eller suppleres med andre eksamensformer $(2,7)$. I Oslo gjennomføres nå stasjonseksamen flere semestre som en kombinasjon av ferdighetsstasjoner («ekte OSCE-stasjoner») og skriftlige kunnskapsstasjoner (7). Dette krever langt mindre tid og ressurser enn tradisjonell klinisk eksamen med pasient og tradisjonell skriftlig eksamen. Selv om logistikken er komplisert, er den gjennomførbar. Klinisk eksamen med «ekte» pasienter har fortsatt en plass, men kan bare forsvares i store kliniske fag som indremedisin, kirurgi og allmennmedisin.

I et drøyt tiår hadde bare en tredel av medisinerkullene i Oslo eksamen i faget dermatologi og venerologi. Det var en tradisjonell klinisk eksamen med pasient og muntlig eksaminering. Et synkende nivå i prestasjonene for de rundt 30 som kom opp, ga mistanke om at mange tok sjansen på at de ikke ville bli trukket ut noen dager før eksamen. Derfor ble stasjonseksamen innført også i dette faget. Med bruk av skuespillere som «pasienter», fotografier av utslett, skriftlige kunnskapsstasjoner og noen få lærere gjennomfører nå nesten 100 studenter per semester stasjonseksamen i faget på én og samme dag. Erfaringene hittil er gode.

Nye eksamensformer i medisin har altså medført at studentene blir testet i større deler av faget og i viktige kliniske ferdigheter og at karakterfastsettelsen blir mer objektiv og konsistent. Bruk av stasjonseksamen gjør det mulig å teste mange studenter på kort tid med begrensede lærerressurser. Dermed har man oppnådd en viktig funksjon med eksamen - at faget blir tatt på alvor av studentene.

\section{Litteratur}

1. Brodal P. Eksamen - myter og realiteter. Tidsskr Nor Lægeforen 1997; 117 489-90.

2. Downing SM, Yudkowski R. red. Assessment in health professions education. New York, NY: Routledge, 2009

3. Dent JA, Harden RM. red. A practical guide for medical teachers. 3. utg. Edinburgh: Churchill Livingstone, 2009.

4. Den medisinske fagprøven for utenlandsmedisinere 2012. www.med.uio.no (25.6.2012).

5. Harden RM, Gleeson FA. Assessment of clinical competence using an objective structured clinical examination (OSCE). Med Educ 1979; 13: 41-54.

6. Jensen P. Roald B. A stå eller å stryke. Tidsskr Nor Lægeforen 1999; 119: 643.

Brodal P. Bruk og misbruk av OSCE. AEsculap 2011; nr. 1: 28-9. 